\title{
Specifications of the Cultivation of Tomato in Hydropon Greenhouses
}

\author{
Abdiev Zafarali Toshtemirovich, Yunusov Salokhiddin Adkhamovich, Z. T. Abdiev, S. A. \\ Yunusov
}

\begin{abstract}
This scientific article is called " Feature stories from the history of the Nurata oasis" and it uses the results of ethnographic field studies from 1999 to 2013, archival documents and scientific literature on this topic, as well as historical and ethnographic comparative information on the basis of dissertations and manuals. The article provides interesting information on the indigenous tribes of the Nurata oasis Oguz-Turkmen, their assimilation over many centuries and their transformation into Uzbek-Turkmen, as well as on other ethnic groups.
\end{abstract}

Keywords: Nurata, ethnic history, historiography, ethnography, ethnic composition, tribe, Oguz, Oguz-Turkmen, nomadic and semi-nomadic people, trade, lifestyle.

\section{INTRODUCTION.}

The effective use of natural resources, the use of new resource-saving innovative technologies, and the expansion of exports of vegetables are the most prior issues on the solution of global food problem. It is important to learn the technology for qualitative products and to meet the demand of the population for seasonal vegetables.

Short periods of cold days in Uzbekistan, with hot period not exceeding 3.0-3.5 months, prolonged sunny days, high solar intensity allow to obtain high yield from greenhouses with low cost. In addition, at the establishment and the use of greenhouses in Uzbekistan the production costs $30-70 \%$ cheaper than in Kazakhstan and Russia.

In recent years, in the countries with developed agriculture like the United States, the Netherlands, Israel, Japan, and South Korea the cultivation of vegetables by the modern, fully automated hydroponic method based on specialized computer programs have been expanded.

A number of decrees and orders have been adopted in the Republic on the development of greenhouse farms and the construction of modern hydroponic greenhouses. These resolutions have intended to increase the production of non-seasonal vegetable products,

Revised Version Manuscript Received on 16 September, 2019.

* Correspondence Author

Abdiev Zafarali Toshtemirovich, Senior teacher, Department of "Vegetable growing, melon Production and potato growing", Tashkent state agrarian university

Yunusov Salokhiddin Adkhamovich, Docent, Department of "Vegetable growing, melon Production and potato growing", Tashkent state agrarian university

Z.T.Abdiev, Department of "Horticulture, melon production and potato growing" Tashkent State Agrarian University, University street, Tashkent, E-mail: zafaralia@inbox.ru

S.A. Yunusov, Department of "Horticulture, melon production and potato growing" Tashkent State Agrarian University, 2, University street, Tashkent, E-mail: salohiddin.yunusov@yandex.ru to train highly competitive and qualified personnel in industry sphere, to provide the population with cheap and qualitative food products, to meet the needs of the organizations of greenhouses and infrastructure to be established in the republic for the qualified specialists in order to increase the production capacity.

According to the forecast of "Modern greenhouse" LLC organization about the development perspectives of greenhouses in the Republic of Uzbekistan in 2018 - 2030, the volume of greenhouses production in the world is estimated at US\$ 12.6 billion with an annual growth rate of 11 percent. By the year 2030, 65-70 thousand hectares of modern greenhouse complexes will operate in the country. In the years of 2018-2030 average 4230.8 hectares annually and total 55 thousand hectares of greenhouse complexes will be established. The main products of these complexes will be vegetables (tomatoes, cucumbers, greens, peppers, etc.), vegetable seedlings, flowers and citrus (lemon and tangerine) plants. At the present the area where tomato is grown has extended over $3.0 \mathrm{mln}$ hectares in the world, its yield is $70-100 \mathrm{t} / \mathrm{ha}$ in the open field, $180-200 \mathrm{t} / \mathrm{ha}$ in greenhouses and $250-350 \mathrm{t} / \mathrm{h}$ in hydroponics.

Creation of modern greenhouse complexes for efficient use of rain-fed and saline lands will make a significant contribution to the economy of the Republic. Cultivation of tomatoes in hydrophilic greenhouses and obtaining higher yields for increasing export is our main goal.

\section{THE METHODS OF THE RESEARCH.}

In 2012, a modern hydropon greenhouse with a total area of $5000 \mathrm{~m}^{2}$ was established in experimental statation of Tashkent state agrarian university within the framework of the project "Construction of a model greenhouses in Uzbekistan with the attraction of grant funds of the Government of the Republic of Korea" and the investigations were conducted in this greenhouse during 2015-2018.

In the experiments the methods were used efficiently such as "The method for state variety-testing of agricultural crops"(M. 1975), methodological recommendation on conducting experiments with vegetable crops in close ground (M. 1976), "Methods of field experiment" (B.A.Dospekhov, 1985), the mehodics on conducting experiments in vegetable growing, melon production and potato growing (B.B.Azimov, B.A.Azimov, 2002).

The main elements of the greenhouse in the experiment were: the top, side 
and surface of land was covered with a special polyethylene film, protective aluminum curtains from the sun's effects on the plant,

heat-retaining right, left and top curtains, nets on the right and left rear, and air humidity regulating equipment. In addition, there existed a ventilation system, sensors (sensors for temperature, humidity and heat), water and mineral fertilizer storage tanks, water and mineral fertilizer mixing systems, seeding cassettes, initial plant block and coconut sawdust, drip irrigation system, heating system ( with gas, oil products) and boiler room. The greenhouse has an automated control system.

In the experimental area located the water source for drip irrigation was Boz-suv canal, 2 water tanks of 5000 liters, pump (carrying water to tank) $-0.82 \mathrm{l} / \mathrm{s}$, water purification filters, water regulating equipment (valves, opening and closing equipments), the devices for fertilizer dissolution and delivery to system, main pipe (polyethylene with diameter $100 \mathrm{~mm}$ ), water distribution pipes (polyethylene, $16 \mathrm{~mm}$ diameter, equipped with a drip device in each $33 \mathrm{~cm}$ ). A total of 15,280 drippers.

In the experiment, the drip irrigation system operates as a result of the pumping $120 \mathrm{l} / \mathrm{h}$ water through closed pipes to the bottles of 10000 liters in 45-50 minutes. Purified and filtered water is delivered main pipe through the automated equipments for water regulation and distribution, and then delivered to plants through dripper pipes.

In drip irrigation systems (A tanker is for macro fertilizers, B tanker - micro-fertilizers and $\mathrm{C}$ tanker - liquid fertilizers) the solution of fertilizers dissolved in water is poured into the bottles with a capacity of 1,000 liters and delivered to main pipe through the taps, then applied to plants by mixing with water. Automatic water distribution system controls the concentration of fertilizer solution by means of an electroconductor device on the water from the drippers, i.e, the water is observed dropping from the top, middle and bottom parts of the drippers of pipes.

The tomato hybrid Rofita F1 was studied in 3 repetitions, in small-sized hydroponic environment intended for 25-50 pieces of plants with different substrates. The used substrates were in different forms such as coconut flakes, gravel, vermiculite, perlite fiber, perlite grinding, wood sawdust and crushed straw. These substrates were placed in polyethylene film bags of $100 \mathrm{~cm}$ length, $10 \mathrm{~cm}$ height and 20 $\mathrm{cm}$ width. The holes were made in bags and then the seedlings were planted.

In a small hydroponic environment, coconut flakes were selected as a control variant out of the substrates.

Phenological and biometric observations were carried out in the experiment. The budding time, flowering, fruiting and fruit maturation time of plant was identified. The yield was picked 31 times and statistically analyzed.

\section{THE RESULTS OF RESEARCH}

On August 2, the seeds of tomato hybrid Rofita F1were sown in 240 cassettes made of a special (foam block) material. Before sowing, the seeds were immersed in a nutrient solution prepared to fully moisten the cracks in the cassettes and then the seeds were sown mulching with vermiculite $(1.5-2 \mathrm{~g})$, then covered with paper and the water was sprayed with special sprayer (0,7-1,0 1 per cassette), covered with black polyethylene film.

In the experiment the preparation of tomato seedlings were performed in a separate section of the greenhouse. Phenological observations showed that the seeds sown in foam block cassettes were fully germinated in 7 days. When the development of seedlings were observed, the number of main leaves made 5-6 pieces and the seedling with $15-18 \mathrm{~cm}$ in length were ready for planting in 23-24 days. The seedlings were transplanted to small hydroponic substrates on August 11, 2015, August 26, 2016 and September 7, 2017 in experimental plot.

Feeding with the solution prepared artificially for tomato cultivation in small-scale hydroponic condition is one of the main factors. In order to prepare the basic solution in the experiment, the fertilizers were divided into 3 parts and dissolved in 1000 litres water, taking into account the water solubility and reaction conditions. At the same time, $100 \mathrm{~kg}$ of $\mathrm{CaNO}_{3}$ fertilizer, $5.7 \mathrm{~kg}$ of $\mathrm{CO}\left(\mathrm{NH}_{2}\right)_{2}$ (corbomide) fertilizer and 700 grams of iron $(\mathrm{Fe})$ were added to the A barrel. $50 \mathrm{kgs}$ of $\mathrm{MgSO}_{4}, 70 \mathrm{kgs}$ of $\mathrm{KSO}_{4}, 15 \mathrm{kgs}$ of $\mathrm{NH}_{4} \mathrm{H}_{2} \mathrm{PO}_{4}$ (ammofos) fertilizer, from macrofertilizers -150 gr of Bor, $150 \mathrm{gr}$ of zinc, $20 \mathrm{gr}$ of copper, $170 \mathrm{gr}$ of manganese were poured to B barrel. While into $\mathrm{C}$ barrel nitrate acid $\left(\mathrm{HNO}_{3}\right)$ of 7,5-8 1 (for enriching solution with $\mathrm{NO}_{3}$ and regulating $\mathrm{Ph}$ value) was poured.

Main solution was transferred to active solution in the experiment by mixing with water (at 1:10 ratio), and the formed concentration of active solution is to be 2,40-2,70, according to ES, and 5,5-6,5 according to $\mathrm{pH}$ value.

During the growth of tomato in the experiment, the number of irrigation was 2041-2101 times, and the irrigation rate was $2,862 \mathrm{~m}^{3}$. Average daily water consumption per plant of the experiment constituted average 0,523 1 in control variant (coconut flake) and in the remaining variants it was 0,5331 . In the experiment, $63.7-75 \%$ of the supplied water for the variants was absorbed by the plant, and the remaining water ran off together with sewage. The largest outflow was observed in the variants 2 and 8 where the tomato seedlings were sown (33.9-36.3\%) in gravel and crushed straw.

The time of plant budding, flowering, fruiting and fruit maturation was determined in the experiment. The data have been presented in Table 1 on the duration of growth stages of tomatoes which were grown in greenhouses.

Table- 1: Duration of growth stages of tomatoes cultivated in small-scale hydroponic method (day)

\begin{tabular}{|c|c|c|c|c|c|c|}
\hline \multirow[b]{2}{*}{ № } & \multirow[b]{2}{*}{ Variants } & \multicolumn{4}{|c|}{ From the planting time of seedling until..... } & \multirow{2}{*}{$\begin{array}{l}\text { From the planting of } \\
\text { seedling till the fruit } \\
\text { maturation }\end{array}$} \\
\hline & & budding & flowering & fruiting & $\begin{array}{l}\text { Fruit } \\
\text { maturation }\end{array}$ & \\
\hline \multicolumn{3}{|c|}{$\begin{array}{l}\text { trieval Number: B14950982S1119/2019@BEIESP } \\
\text { OI: 10.35940/ijrte.B1495.0982S1119 }\end{array}$} & 3796 & \multicolumn{2}{|c|}{$\begin{array}{l}\text { Published By: } \\
\text { Blue Eyes Intelligence Engineering } \\
\text { \& Sciences Publication }\end{array}$} & \\
\hline
\end{tabular}




\begin{tabular}{|l|l|c|c|c|c|c|}
\hline 1 & Coconut flake (control) & 41 & 10 & 13 & 40 & 105 \\
\hline 2 & Gravel & 38 & 9 & 12 & 37 & 96 \\
\hline 3 & Perlite grains & 40 & 9 & 10 & 38 & 97 \\
\hline 4 & Vermiculite & 39 & 9 & 11 & 37 & 96 \\
\hline 5 & Perlite fiber & 44 & 11 & 13 & 40 & 108 \\
\hline 6 & Wood sawdust & 45 & 11 & 12 & 40 & 98 \\
\hline 7 & $\begin{array}{l}\text { Wood sawdust +manure } \\
(50 x 50)\end{array}$ & 42 & 9 & 11 & 38 & 100 \\
\hline 8 & Mineral cotton & 40 & 8 & 12 & 39 & 99 \\
\hline
\end{tabular}

In the experiment, the earliest period of budding after planting was 38-39 days in the gravel and vermoculite variants. The remaining options were 40-45 days.

The first flowering phase of tomato was observed in 8 days after budding in the variant where the tomato was planted in mineral cotton. In other variants it was 9-11 days. The variants planted on perlite fiber and wooden sawdust flowered one day later than the control variant.

It was known that the variants grown in mineral wadding flowered 2 days earlier than the control variant in the days from the planting of seedlings till the flowering period.

When the beginning of fruit maturation of tomato was observed in the experiment, the control variant and the variant planted in perlite fiber began to bear fruit at the same time in 13 days, and the remaining variants yielded in 10-12 days.

The beginning of the ripening phase of tomato fruits also differed from each other in the experiment. It was found out that the variants planted in gravel and vermiculite ripened earlier than the other, at 37 days. The late-matured variants were coconut, perlite fiber and wood sawdust variants, in which the fruits ripened for 40 days.

During the cultivation of tomatoes in various substrates under small-scale hydroponics, a period from the planting of seedlings till fruit ripening. Hereby, the control variant planted in coconut flakes made 105 days. The earliest variants grown in gravel and vermoculture matured in 96 days. Such substrates allow the tomato plant to ripen relatively early because of moderate heat, good breathing of the roots, and low moisture content. Late-matured variant perlit fiber was 108 days. This is due to the hardness of perlite fiber and poor development of the root system. In the experiment decreasing irrigation intervals was due to the low irrigation norms and the fact that each irrigation provided with a small amount of mineral fertilizers in combination with water, which had a positive effect on the growth and development of the plants allowing 3 to 4 days earlier growth phase.
Biometric observations on tomato growth and development were conducted. And the results of these observations have been presented in Table 2 .

In the experiment, tomato seedlings were planted in polyethylene bags by three pieces in each variant, and calculations were done in the first 10 plants of the plot. Also the length of the main stem, the number of spikes, and the number of fruits were determined per plant. Observations were carried out from October to May at the beginning of each month during 8 months.

According to the results, the variants with the highest growth of the main stem of tomato in October were $86-88 \mathrm{~cm}$ in gravel and mineral wadding, while the low stems of $80-81 \mathrm{~cm}$ were noted in the $1 \mathrm{st}$ and $3 \mathrm{rd}$ versions. According to this indicators at the last observations in May, the length of stems were identified by variants. The longest stem variant was $632-674 \mathrm{~cm}$ in coconut flakes, manure mixed with wooden sawdust and in mineral wadding substances. The minimum stem length was $528-571 \mathrm{~cm}$ in variants grown in perlite fiber and gravel. In other variants, the stem had a length of $587-630 \mathrm{~cm}$.

In October, when the number of cluster of tomatoes was counted on the stem, they were the same in all variants by one piece. But in the next months there has been a dramatic change in plant growth. The variant with the highest number of fruit cluster was 12 to 13 pieces in coconut flakes, wooden sawdust mixed with manure, perlite grains, and in mineral wadding substrates. The lowest number of clusters was 6-10 pieces in perlite fiber and gravel variants.

Of course, in practice, an increase in the number of cluster of tomato plants leads to an increase in the number of fruits and yields. Complete improvement of fruit means the ability to grow and produce fruits depending on the proper conditions and timely delivery of nutrients. 
Specifications of the Cultivation of Tomato in Hydropon Greenhouses

2-жадвал

The growth and development of tomato under the cultivation in small-scale hydroponic method

\begin{tabular}{|c|c|c|c|c|c|c|c|c|c|c|c|c|c|c|c|c|c|c|c|c|c|c|c|c|c|}
\hline \multirow[t]{3}{*}{ № } & \multirow[b]{3}{*}{ variants } & \multicolumn{24}{|c|}{ Months of biometrical observations } \\
\hline & & \multicolumn{3}{|c|}{$\mathrm{X}$. } & \multicolumn{3}{|c|}{ XI. } & \multicolumn{3}{|c|}{ XII. } & \multicolumn{3}{|c|}{ I. } & \multicolumn{3}{|c|}{ II. } & \multicolumn{3}{|c|}{ III. } & \multicolumn{3}{|c|}{ IV. } & \multicolumn{3}{|c|}{$\mathrm{V}$. } \\
\hline & & 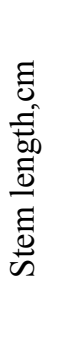 & 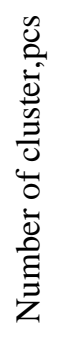 & 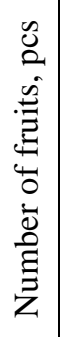 & 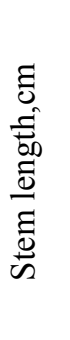 & 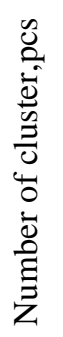 & 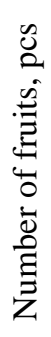 & 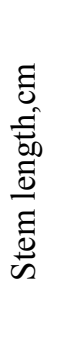 & 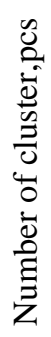 & 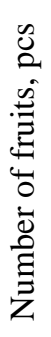 & 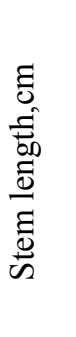 & 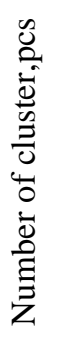 & 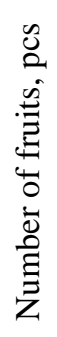 & 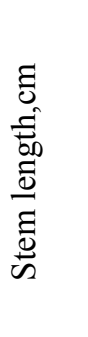 & 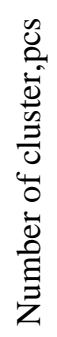 & 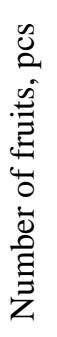 & 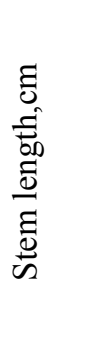 & 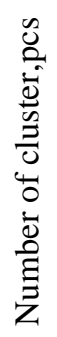 & 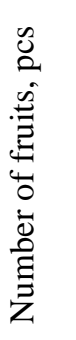 & 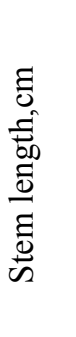 & 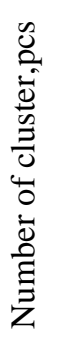 & 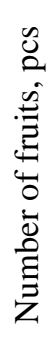 & 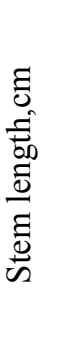 & 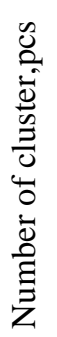 & 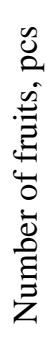 \\
\hline 1 & Coconut (control) & 80 & 1 & - & 166 & 2 & 2 & 261 & 5 & 15 & 345 & 6 & 9 & 378 & 7 & 10 & 446 & 8 & 13 & 574 & 11 & 8 & 664 & 13 & 3 \\
\hline 2 & Gravel & 86 & 1 & - & 166 & 2 & 2 & 261 & 5 & 15 & 319 & 7 & 8 & 346 & 7 & 10 & 452 & 8 & 13 & 519 & 9 & 7 & 571 & 10 & 2 \\
\hline 3 & Perlite grains & 81 & 1 & - & 168 & 2 & 2 & 247 & 7 & 14 & 347 & 7 & 7 & 381 & 7 & 10 & 427 & 8 & 16 & 554 & 10 & 7 & 630 & 12 & 3 \\
\hline 4 & Vermiculite & 85 & 1 & - & 170 & 2 & 2 & 262 & 7 & 15 & 338 & 7 & 8 & 357 & 7 & 10 & 462 & 8 & 16 & 545 & 9 & 8 & 587 & 10 & 3 \\
\hline 5 & Perlite fiber & 80 & 1 & - & 165 & 2 & 1 & 261 & 5 & 9 & 345 & 5 & 7 & 352 & 6 & 9 & 376 & 6 & 11 & 512 & 6 & 5 & 528 & 6 & 1 \\
\hline 6 & Wood sawdust & 80 & 1 & - & 165 & 2 & 2 & 254 & 7 & 13 & 345 & 6 & 10 & 384 & 7 & 11 & 461 & 7 & 12 & 532 & 10 & 6 & 618 & 11 & 2 \\
\hline 8 & Mineral cotton & 88 & 1 & - & 168 & 2 & 2 & 254 & 7 & 13 & 367 & 8 & 10 & 400 & 6 & 9 & 448 & 7 & 16 & 576 & 11 & 7 & 674 & 13 & 2 \\
\hline
\end{tabular}


The number of fruits per plant increased from 9 to 15 pieces in the variants from October to December, and by March this indication dropped and again raised to 11-16 in March. Then it went down again in the following months. This is because of the crop was harvested by ripening, which varied over the months. At the end of the growing season, the number of fruits decreased.

When the tomato was cultivated on various substrates in he experiment, the growth and development of the plant yielded better results in substrates such as coconut flakes, mineral cotton and wood sawdust mixed with manure.

The results of the research revealed the influence of tomato cultivation in various substrates under small hydroponic conditions on the productivity of the plant. Hereby, the yield in each harvesting was weighed as per variant, marketable and non-marketable yield were differentiated and the calculations were carried out.

The yield indicators from one square meter of tomato in the experiment are shown in Table 3.

Table-3: The productivity of the tomato grown in small-scale hydroponic condition $\left(\mathrm{kg} / \mathrm{m}^{2}\right)$

\begin{tabular}{|l|l|c|c|c|c|c|}
\hline № & \multicolumn{1}{|c|}{ Variety samples } & $\begin{array}{c}\text { Average } \\
\text { mass of fruit, } \\
\mathrm{g}\end{array}$ & $\begin{array}{c}\text { Total yield, } \\
\mathrm{kg} / \mathrm{m}^{2}\end{array}$ & $\begin{array}{c}\text { Share of } \\
\text { marketable } \\
\text { product, } \%\end{array}$ & $\begin{array}{c}\text { Marketable } \\
\text { product, } \\
\mathrm{kg} / \mathrm{m}^{2}\end{array}$ & $\begin{array}{c}\text { Compared to } \\
\text { control \% }\end{array}$ \\
\hline 1 & Coconut (control) & 180 & 20,3 & 92,5 & 18,8 & 100 \\
\hline 2 & Gravel & 145 & 15,6 & 87,6 & 13,7 & 73 \\
\hline 3 & Perlite grains & 152 & 16,6 & 88,9 & 14,8 & 79 \\
\hline 4 & Vermoculite & 131 & 16,7 & 89,4 & 14,9 & 79 \\
\hline 5 & Perlite fiber & 147 & 17,3 & 90,1 & 15,6 & 83 \\
\hline 6 & Wood sawdust & 148 & 17,2 & 89,6 & 15,4 & 92 \\
\hline 7 & $\begin{array}{l}\text { Wood sawdust +manure } \\
\text { (50x50) }\end{array}$ & 172 & 19,2 & 91,6 & 17,6 & 94 \\
\hline 8 & Mineral wadding & 174 & 20,0 & 92,0 & 18,4 & \\
\hline & LAD 05 & 12,0 & & & 1,8 & 98 \\
\hline & P, $\%$ & 3,1 & & & 4,6 & \\
\hline
\end{tabular}

According to the results of the research, the yield of tomato was divided into marketable and unmarketable yield and the average weight of fruit was determined. Among the variants the highest mass 172-180 grams was noted in coconut flakes, mineral wadding and wood sawdust with manure substrates. While the lowest indication 131 grams was noted in the variant of vermiculite. In other variants, this indication constituted 145-152 grams.

The share of total yield and marketable yield was determined in practice. At the same time from unmarketable yield were distinguished deformational, curved fruits, double and rotten, even damaged fruits.

In the experiment, the marketable yield was also distinguished among the variants. At the same time, the highest marketable yield was obtained in the control variant, i.e, $18.8 \mathrm{~kg}$ per square meter of the substrate of coconut flakes. In the other $7^{\text {th }}$ and $8^{\text {th }}$ variants, we obtained 17.6-18,4 $\mathrm{kgs}$ of yield. The share of marketable yield in these variants constituted 91.9-92.5\%. Other variants had unmarketable yield of 9.1 to $12.4 \%$. This is due to the influence of the substrates and the environment in the plant root system, as well as nutrient deficiencies.

In the experiment, it was found out that in the cultivation of tomato plants on small substrates by hydroponics method the most effective organic substrate was coconut flakes, which was selected as control variant. Compared to control variant, $2 \%$ and $6 \%$ less yield was obtained from the variants in mineral cotton mixed with manure and wood sawdust which was closer to the control variant. The remaining variants yielded $17-27 \%$ less than the control. In the experiment, a relatively low yield was observed in the variants grown in gravel and vermeculite, which accounted for $73-79 \%$ than the control.
The main reason for the relatively high yield of variants in the experiment was the effect of the substrates used. This is because the root system is conducive to plant growth and development, that is, because the substrates can retain moisture, breathe, rapidly absorb macro and micro fertilizer solutions during the growing season, and the root system maximizes nutrients during plant growth.

\section{CONCLUSION}

Experiments in tomato cultivation on various substrates have shown good results in coconut flakes, mineral wadding and wood sawdust with manure substrates. The average weight of tomato fruit is 172-180 grams in the variants of coconut flakes, mineral cotton and wood sawdust. In the version of coconut flakes, the highest marketable crop yielded $18.8 \mathrm{~kg}$ per square meter. In the variant planted in mineral cotton weighing $18.4 \mathrm{~kg}$ of wood sawdust and $17,6 \mathrm{~kg}$ in manure added variant. The share of marketable yield in these variants was $91.9-92.5 \%$.

\section{REFERENCE}

1. Azimov B.J., Azimov B.B. The methodics on conducting experiments in vegetable growing, melon production and potato growing. National encyclopedia of Uzbekistan. 2002. P-224.

2. Dementyev A.V. Drip irrigation of tomato in the condition of interfluve area of Volga-Don rivers.-M.: in 2004.

3. Dobrov V. Cultivating vegetables in greenhouses and closed seedbeds - M.: Kolos, 2008. p- 287.

4. Duhovniy V.A. Drip irrigation- perspective and introduction -T.:SANIIRI. In 1995.

5. Dospekhov B.A. Methods on field experiments. edit. 5-M. Agropromizdat. 1985. P-361 
6. V.I.Zuyev, A.A.Atakhodjayev, Sh.I.Asatov, A.K.Kodirkhojayev, U.I.Akramov "vegetable growing in protected area". Tashkent "Economics-finance". 2014.p- 350.

7. Lyan E, Niyazov M. Vegetable growing in greenhouses. Uzbekistan agriculture journal №12. 2011.p- 3-4.

8. Methodics of state variety testing of agricultural crops. The $4^{\text {th }}$ edition. Potato, vegetable and melon culture. M., Kolos, 1975.

9. Methodical recommendation on conducting experiments with vegetable crops in protected areas ground.- M., 1976.p -108.

10. Papanov A. N., Zakharchenko, E.P. Vegetables in protected area. Perm. Perm edition, 1989. P-240. 